\title{
Economic Analysis of Homestead Fish Production in Ogun State Nigeria
}

\author{
A.T. Olawumi ${ }^{1}$, A. O. Dipeolu ${ }^{2}$ and O. M. Bamiro ${ }^{3}$ \\ ${ }^{1}$ Agricultural Production and Management Sciences, Tai Solarin University of Education, \\ Ijebu - Ode, Ogun State, Nigeria \\ ${ }^{2}$ Department of Agricultural Economics and Farm Management, University of Agriculture, \\ Abeokuta, Nigeria \\ ${ }^{3}$ Department of Agricultural Economics, Olabisi Onabanjo University, Yewa Campus, \\ Ayetoro, Nigeria
}

KEYWORDS Homestead. Fish Farming. Clarias. Heteroclarias. Aquaculture

\begin{abstract}
This study examines the determinants of revenue of homestead fish production in Ogun State, Nigeria. Descriptive statistics, budgetary and regression models were the tools employed for the analysis of data obtained from 72 fish farmers. Most of the farmers are within the economically active age bracket, having a mean household size of 6 with high level of educational status. Farmers in the study area practiced mono-culture and poly-culture fish farming. Sole clarias enterprise recorded the lowest net farm income while Tilapia/heteroclarias enterprise has the highest net farm income. The quadratic functional form is chosen as the lead equation. The pond size, quantity of fish seeds stocked other significant, determinants of the revenue that accrue to homestead fish production in Ogun state, Nigeria. This study therefore suggests that policy variables such as pond size, labour and fingerlings that influence the aquaculture revenue should be strengthened for sustainable fish production to be attained in Ogun State and in Nigeria.
\end{abstract}

\section{INTRODUCTION}

Protein intake in developing countries are below the required $75 \mathrm{~g}$ per person per day (FAO $1995)$ and the Nigerian population is growing at about $4 \%$ per annum as against livestock production, which is growing at about just $2 \%$ per annum (Owolabi 2002). Talabi (2004) stated that statistics and researches have further shown that meat protein shortage continues to increase everyday in Nigeria, despite various efforts to improve its productivity in the field of cattle production and the price of beef has become unaffordable for an average consumer. The awareness of the need for adequate protein in human diet has greatly increased in many developing regions of the world and fish has been widely acknowledged as a rich source of dietary protein (Ajayi 2001). Akinyemi (1998) projected that fish demand would increase from 1.392 million tones in 2001 to about 1.688 million tones in 2010. Recent accounts show that domestic demand (because of progressive increase in the Nigeria population with over 140 million people) for fish in Nigeria could not be met only by dependence on artisanal fisheries, which experts say is fast depleting (Ojo and Fagbenro 2004). This observation, contradicts the report of the FAO-World Fish Center workshop on small-scale aquaculture in Sub-Saharan Africa in 2004, which identified Nigeria as one of the country in the region with great potential to attain sustainable fish production, via aquaculture considering extensive mangrove ecosystem available in the country (FAO 2005). The annual state of economic report by sector published by Central Bank of Nigeria shows that, Nigeria imports over US\$200 million worth of frozen fish per annum. This, however, accounts for over $50 \%$ of fish consumed annually to offset the gap in the domestic demand in the country (CBN 2006).

The overall economic objective of aquaculture (the rearing of fish and other aquatic organism in an enclosed water body called pond) is to produce maximum weight of marketable fish or shrimp from a given volume of water in a shortest time at the least cost (Papka 1993; Ogundari and Ojo 2009). According to Duarte et al. (2000), the total production of fisheries in 2004 was 140.5 million tonnes of which aquaculture contributed 45.5 million tonnes or about $32 \%$ of the total world production. There have been consistent calls for increased investment in aquaculture to boost fish production in developing countries (such as Nigeria). Report of successful introduction and adoption of homestead fish production had been given by the Ogun State Agricultural Development Programme (OGADEP 2004). 
In order to achieve the much-desired increased fish production to match the ever widening gap between production and demand, there is a need for research into the various factors that determine the revenue realizable from homestead fish farming with a bill to encourage more investors to produce at economically profitable levels.

\section{METHODOLOGY}

The study was carried out in the zonal headquarters of Ogun State Agricultural Development Programme (OGADEP), which are Abeokuta, Ikenne, Ilaro and Ijebu - Ode. The purposive technique was used to select twentyfive (25) homestead fish farmer in each of the four OGADEP's zonal headquarters making a total of hundred (100) respondents. Responses from 72 respondents were used in the analysis due to incomplete supply of data. Structured questionnaires was administered on the sample homestead fish farmers to get data on both socioeconomic and production variables through the assistant of the Village Extension Agents (VEA's) of OGADEP. Some of the data collected from the farmers are age, sex, education, size of pond, species of fish raised, input used and their cost, labour types and wages, output/yield and prices of the products.

\section{Model Specifications}

(a) Budgetary Analysis

The Net Farm Income (NFI) was obtained thus:

$\mathrm{NFI}=\mathrm{TR}-\mathrm{TC}$.

$\mathrm{TC}=\mathrm{TFC}_{\mathrm{i}}+\mathrm{TVC}_{\mathrm{i}}$

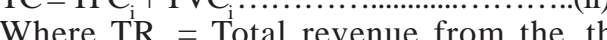
enterprise (Naira)

$\mathrm{TVC}_{\mathrm{i}}=$ Total Variable cost from ${ }_{\mathrm{i}}$ th enterprise (Naira)

TFC $_{i}=$ Total fixed cost of th enterprise (Naira)

$\mathrm{TC}_{\mathrm{i}}=$ Total cost of th enterprise (Naira)

NFI = Net Farm Income (Naira)

\section{Production Function}

The determinants of the revenue from homestead fish farming in Ogun State was examined by multiple regression analysis using ordinary least square (OLS) techniques. The estimated model is implicitly stated as:
Rev =f(psze, qfsd, lfdg, lhar, dlim, dfer, drat, dpwa, syst, e)....

Where;

Rev $=$ total revenue per production season (naira)

Psze $=$ pond size $\left(\mathrm{m}^{2}\right)$

Qfsd = quantity of fish seeds (number of fingerlings)

Lfdg = labour for feeding (number of man per hour)

Lhar $=$ labour of harvesting (number of man per hour)

dlim = dummy variable for using lime ( 1 if used, 0 otherwise)

dfer = dummy variable for using fertilizers ( 1 if used, 0 otherwise)

drat $=$ dummy variable for using ration feed ( 1 if used, 0 otherwise)

dpwa = dummy variable for using poultry waste (1 if used, 0 otherwise)

syst $=$ fish culture system dummy $($ polyculture $=$ 1 , monoculture $=0$ )

$\mathrm{e}=$ error term.

Four functional forms were estimated (linear, semilog, doublelog and quadratic). The lead equation (quadratic functional form) was selected on the basis of economic, statistical and econometric criteria.

\section{RESULT AND DISCUSSION}

\section{Socio-economic Characteristics of Homestead Fish Farmers in Ogun State}

Age, sex, marital status educational status and household size, among others are the socioeconomic characteristics of the fish farmers that are considered in this study. The result is presented in table 1. A greater percentage of the homestead fish farmers fall between the ages of 40-49, indicating that most of them are within the economically active population and therefore constitute a good labour force for fishery enterprise with the expectation that they would be good managers of limited available resources. The result further shows that the production of homestead fish in Ogun State is gender biased, as male represents 92 percent of the fish farmers in the state. Majority of the fish farmers are married with the mean household size of 6 . This implies that the fish farmers have adequate family members that can provide cheap labour, which is a major characteristic of farmers in the study area. In addition, most of the homestead fish farmers 
Table 1: Socio-economic characteristics of homestead fish farmers in Ogun State

\begin{tabular}{|c|c|c|}
\hline Characteristics & Frequency & Percentage \\
\hline \multicolumn{3}{|l|}{ Age (years) } \\
\hline$<30$ & 2 & 2.78 \\
\hline $30-39$ & 17 & 23.61 \\
\hline $40-49$ & 27 & 37.5 \\
\hline $50-59$ & 15 & 20.83 \\
\hline $60-69$ & 10 & 13.89 \\
\hline$\geq 70$ & 1 & 1.39 \\
\hline \multicolumn{3}{|l|}{$\operatorname{Se\overline {x}}$} \\
\hline Male & 66 & 91.67 \\
\hline Female & 6 & 8.33 \\
\hline \multicolumn{3}{|l|}{ Marital Status } \\
\hline Single & 4 & 5.56 \\
\hline Married & 63 & 87.5 \\
\hline Widowed & 1 & 1.39 \\
\hline Divorced & 4 & 5.56 \\
\hline \multicolumn{3}{|l|}{ Educational Status } \\
\hline No formal education & 5 & 6.94 \\
\hline Primary & 12 & 16.67 \\
\hline Secondary & 21 & 29.17 \\
\hline Tertiary & 34 & 47.22 \\
\hline \multicolumn{3}{|l|}{ Household Size } \\
\hline $0-2$ & 12 & 16.67] \\
\hline $3-5$ & 29 & 40.27 \\
\hline $6-8$ & 17 & 25.00 \\
\hline $9-11$ & 8 & 11.12 \\
\hline$\geq 12$ & 5 & 6.95 \\
\hline
\end{tabular}

have tertiary education, which is expected to translate into high output and efficiency in fish production.

\section{Cost-return Structure of Homestead Fish Farming in Ogun State}

The cost and returns to homestead (concrete) tank fish farming in Ogun State is presented in table 2. It shows that homestead fish farming is profitable at the present level of technology and resources. The net farm income (NFI) ranges from A102,660.65 for Tilapia/heteroclarias enterprise

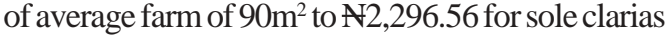
of average farm size of $170.92 \mathrm{~m}^{2}$

The result further shows that the variable cost constitutes the lion share in all the enterprise combinations. However, with respect to the proportion of the variable cost in all the enterprises, it is highest $(89.01 \%)$ in Tilapia/ heteroclaria enterprise and the lowest value $(70.40 \%)$ was recorded in Tilapia/claria mix. The labour cost, cost of fingerlings and cost of feed constitute the lion share of the variable cost in tilapia/heteroclarias enterprise, tilapia/clarias and sole heteroclarias respectively.

\section{Determinants of Revenue in Homestead Fish Production in Ogun State}

The determinants of revenue in homestead fish production in Ogun State are presented in

Table 2: Costs and returns to homestead fish farmers in ogun state

\begin{tabular}{|c|c|c|c|c|c|c|c|c|}
\hline \multirow[t]{2}{*}{$\begin{array}{l}\text { Enterprise } \\
\text { item }\end{array}$} & \multicolumn{2}{|c|}{$\begin{array}{l}\text { Sole } \\
\text { Clarias }\end{array}$} & \multicolumn{2}{|c|}{$\begin{array}{c}\text { Sole } \\
\text { Heteroclarias }\end{array}$} & \multicolumn{2}{|c|}{$\begin{array}{c}\text { Tilapial } \\
\text { Clarias mix }\end{array}$} & \multicolumn{2}{|c|}{$\begin{array}{c}\text { Tilapial } \\
\text { Heteroclarias mix }\end{array}$} \\
\hline & Amount & $\begin{array}{l}\% \text { of } \\
\text { Total }\end{array}$ & Amount & $\begin{array}{l}\% \text { of } \\
\text { Total }\end{array}$ & Amount & $\begin{array}{l}\% \text { of } \\
\text { Total }\end{array}$ & Amount & $\begin{array}{l}\% \text { of } \\
\text { Total }\end{array}$ \\
\hline Total revenue(\#) & $32,753.52$ & & $75,652.88$ & & $98,475.12$ & & $130,217.28$ & \\
\hline \multicolumn{9}{|l|}{ Variable Cost (\#) } \\
\hline Labor cost & 8381.82 & 36.36 & 6191.67 & 37.03 & 3700 & 12.56 & 11033.33 & 44.98 \\
\hline \multirow[t]{2}{*}{ Cost of fingerlings } & & 31.55 & & 14.5 & & 63.31 & & \\
\hline & 7272.7 & 14.62 & 2424.58 & 48.47 & 18650 & 18.5 & 8485.33 & 34.59 \\
\hline Cost of feeds & 3370.2 & & 8103.33 & 75.74 & 5450.32 & & 2480 & 10.11 \\
\hline Cost of fertililer/lime & 4025.1 & 17.46 & 0 & & 1656.7 & 5.62 & 50 & 2.04 \\
\hline Total variable cost & 23049.82 & 75.68 & 16719.58 & & 29457.02 & 70.4 & 24528.99 & 89.01 \\
\hline \multicolumn{9}{|l|}{ Fixed Cost (\#) } \\
\hline \multicolumn{9}{|l|}{$\begin{array}{l}\text { Rent/overhead } \\
\text { (pond construction) }\end{array}$} \\
\hline $\begin{array}{l}\text { Fixed cost depreciated } \\
\text { (water pump, hook, } \\
\text { net,etc.) }\end{array}$ & d 4801.31 & & 3140.08 & & 6250 & & 2152.78 & \\
\hline \multirow[t]{2}{*}{ Total fixed $\operatorname{cost}(\#)$} & $2605-80$ & & 2215.72 & & 6136.67 & & 874.86 & \\
\hline & 7407.14 & 24.32 & 5355.8 & 24.26 & 12386.67 & 29.6 & 3027.64 & 10.99 \\
\hline Total Cost(\#) & $30,456.96$ & & $22,075.38$ & & $41,843.67$ & & $27,556.63$ & \\
\hline Net farm income(\#) & $2,296.56$ & & $53,577.50$ & & $40,631.69$ & & $102,660.65$ & \\
\hline $\begin{array}{l}\text { Average pond size } \\
\text { per enterprize }\end{array}$ & 170.92 & & 83.28 & & 47.21 & & 90 & \\
\hline No of farmers & 9 & & 18 & & 19 & & 3 & \\
\hline
\end{tabular}


Table 3: Regression model estimation for homestead fish production in Ogun State

\begin{tabular}{|c|c|c|c|c|c|}
\hline \multicolumn{2}{|c|}{ Model/Variables } & \multirow{2}{*}{$\begin{array}{c}\text { Linear } \\
(1.150)\end{array}$} & Semi-log & Double-log & Quadratic \\
\hline Constant & 149297.5 & & $-145267 \quad(-0.762)$ & $9.659 * * * \quad(7.549)$ & $-1293.61 \quad(-0.013)$ \\
\hline Pse & 28.951 & $(1.215)$ & $40238.19 \quad(1.388)$ & $0.192 \quad(0.986)$ & $523.783 * * * \quad(2.790)$ \\
\hline Qfsd & 11.838 & $(1.702)$ & $21887.56 \quad(0.846)$ & $0.164 \quad(0.942)$ & $55.633 \quad(2.883)$ \\
\hline Lfdg & -79252.0 & $(-0.979)$ & $-159936 \quad(-1.265)$ & $-0.313 \quad(-0.369)$ & 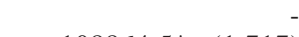 \\
\hline Lhar & 15172.94 & $(0.692)$ & $1032.42 \quad(0.016)$ & $0.117 \quad(0.278)$ & $108864.5^{*} \quad(1.717)$ \\
\hline Dlim & 77108.67 & $(1.522)$ & $58625.16 \quad(1.165)$ & $0.607 * \quad(1.797)$ & $27046.12 \quad(0.690)$ \\
\hline Dfer & -38139.10 & $(-0.493)$ & $-40345.59 \quad(-0.486)$ & $-0.326 \quad(-0.584)$ & $-17840.8 \quad(0.296)$ \\
\hline Drat & 56329.94 & $(0.751)$ & $42094.59 \quad(0.564)$ & $-0.238 \quad(-0.584)$ & $36834.54 \quad(0.650)$ \\
\hline Dpwa & $-128203 * *$ & $(-2.273)$ & $117781 * * \quad(-2.101$ & $-0.569 \quad(-1.511)$ & $101316 * * \quad(-2.385)$ \\
\hline Syst & 61912.43 & $(0.924)$ & $62784.52 \quad(0.968)$ & $0.063 \quad(0.145)$ & $29094.3 \quad(-0.546)$ \\
\hline $\mathrm{Pse}^{2}$ & & & & & $-0.0584 * * \quad(-2.565)$ \\
\hline $\mathrm{Qfsd}^{2}$ & & & & & $0.00260 * * * \quad(-3.000)$ \\
\hline $\operatorname{Lfdg}^{2}$ & & & & & $-62470.80 * * * \quad(-2.909)$ \\
\hline Lhar2 & & & & & $1.9682 .3 * \quad(-1.905)$ \\
\hline $\mathrm{R}^{2}$ & & 0.469 & 0.479 & 0.401 & 0.734 \\
\hline Adjusted $\mathrm{R}^{2}$ & & 0.319 & 0.332 & 0.233 & 0.624 \\
\hline Fstat & & 3.138 & $3.268 * * *$ & 3.268 & $6.670 * * *$ \\
\hline Durbin Watson & & 2.062 & 1.814 & 1.814 & 1.746 \\
\hline
\end{tabular}

table 3. Four functional forms were tried and the lead equation (Quadratic) was chosen on the basis of satisfying economic and econometric criteria. The $\mathrm{R}^{2}$ is 0.734 indicating that $73.4 \%$ of the variation in the revenue is explained by the explanatory variables. The coefficients of pond size, together with its square and the square of labour for feeding are significant at $1 \%$ probability level while the coefficients of labour for harvesting and its square are significant at $10 \%$ probability level. The results in table 3 further show that pond size, quantity of fish seed, labour for harvest have significant and positive influence while their respective squares and the dummy variable for the usage of poultry waste significantly and negatively influenced the revenue that accrued from homestead fish production in Ogun State. These results are in consonance with the findings of (Sani et al. 1991; Ogundari and Ojo 2009). The positive influence of the explanatory variables and the respective negative influence of the squares of the variables signify that the revenue that accrued from fish farming will increase with increase in the utilization of the variable inputs and at a level of each variable input maximum revenue will be realized. A further increase in the utilization of the variable inputs beyond the level that corresponds with maximum revenue will result in a decline in revenue. The negative influence of the usage of the poultry waste on the revenue generation from homestead fish production signifies that farmers should feed their fish with formulated ration.

\section{CONCLUSION}

This study examines the determinants of revenue of homestead fish production in Ogun State, Nigeria. Data collected from 72 fish farmers were used for analysis. Most of the farmers are within the economically active age bracket, having a mean household size of 6 with high level of educational status. Tilapia/heteroclarias enterprise has the highest net farm income while sole clarias recorded the lowest net farm income. The production curve of the homestead fish farmer is quadratic in nature. The pond size, quantity of fish seeds stocked, labour in feeding and harvesting and the use of poultry waste feeds are the major determinants of the revenue that accrue to homestead fish production in Ogun State, Nigeria. This study therefore suggests that policy variables such as pond size, labour and fingerlings that influence the aquaculture revenue should be strengthened for sustainable fish production to be attained in Ogun State and Nigeria as a whole.

\section{REFERENCES}

Akinyemi O 1998. Sustainable Management of Nigeria Fisheries in the $21^{\text {st }}$ Century. Faculty of Agriculture and Forestry. Ibadan: University of Ibadan.

Ajayi OY 2001. Economics of Fish Farming in Remo and Ijebu Division of Ogun State, Nigeria. B. Agric. Dissertation, Unpublished. Department of Agricultural Economics and Farm Management, Ogun State Univeresity.

Duarte AO, Phelps RP 2000. Family Scale Fish Farming 
in Guatemala, Economics Viability of Fish Farming. Journal of Aquaculture in the Tropics, 10(1): 5772 .

CBN 2006. Annual Report and Statement of Account of Central Bank of Nigeria for the year ended 31st December, 2005

FAO 1995. Yearbook Production. Vol 45. Rome: FAO

FAO 2005. Report Of The FAO-Worldfish Center Workshop on Small-Scale Aquaculture in Sub Saharan Africa: Revisiting the Aquaculture Target Group Paradigm. FAO Rome Publication. ftp:// ftp.fao.org/docrep/ fao/008/a0038e/a0038e00.pdf.

Owolabi OO 2002. Wildlife contribution to meat protein consumption in the rural community in southwestern Nigeria. Proceeding of the $27^{\text {th }}$ annual Conference Nigeria Society for Animal Production (NSAP) March 17 -21, Akure.

OGADEP 2004. Ogun State Agricultural Development Programme. Fisheries unit working paper.
Papka PMS 1993. Conservation: Some search Areas for Policy in Nigeria. FORMECU/STAT/PUB/No: 14:51 Ogundari K, Ojo SO 2009. An Examination of Income Generation Potential of Aquaculture Farms in Alleviating Household Poverty: Estimation and Policy Implications from Nigeria Turkish Journal of Fisheries and Aquatic Sciences, 9: 39-45.

Ojo SO, Fagbenro OA 2004. Poverty Reduction Strategy in Nigeria -Improving productivity and Technical Efficiency in Artisanal Fisheries in Niger Delta Region. Paper presented at the 12 th Bi-annual conference of the International Institute of Fisheries Economics and Trade (IIFET), Tokyo, Japan.

Tobor JG 1997. The Fish Industry in Nigeria: Status and Potential for Self Sufficiency in Fish Production. Nigeria Institute of Maritime NIOMR Technical Paper, 54: 34. Sani RM, David AE Kushwalia, Mbanasor J 1991 Economic Analysis of Fish Farming in Bauchi State. Tropical Journal of Animal Science, 1: 75-83 